\title{
Hz. Peygamber Döneminde Düşünce Özgürlüğü ve Muhalefet
}

İhsan ARSLAN*

Freedom of Thought and Opposition in the Time of Prophet Muhammad

Citation/@): Arslan, İhsan, (2018). Freedom of Thought and Opposition in the Time of Prophet Muhammad, Milel ve Nihal, 15 (2), 108-133.

Abstract: In this study, it is dealt with the freedom of thought and opposition in the time of prophet Muhammad (pbuh) through methodological points of view and, had used the basic sources of Islamic history as reference basis. It is emphasized that freedom of thought and expression must be evaluated in the framework of basic human rights, which is obtained by birth, and constructive opposition have also important for self-test mechanism. In this context, it is pointed out that prophet Muhammad had asked his companions' feelings and thoughts, he had adapted the opinion of majority even if it had become contrary to his thought, and he had also welcomed with maturity those who opposed his decisions.

Keywords: Prophet Muhammad, freedom of thought, freedom of expression, opposition, companion.

* Doç. Dr., Recep Tayyip Erdoğan Üniversitesi, İlahiyat Fakültesi, İslâm Tarihi Anabilim Dalı [ihsanarslan70@hotmail.com]. 
Atıf/C: Arslan, İhsan, (2018). Hz. Peygamber Döneminde Düşünce Özgürlüğü ve Muhalefet, Milel ve Nihal, 15 (2), 108-133.

Öz: Bu araştırmada Hz. Peygamber döneminde düşünce özgürlüğü ve muhalefeti, bilimsel araştırmalara özgü metodolojik bakış açısıyla işlenmiş, referans kaynağı olarak İslâm tarihinin temel kaynakları kullanılmıştır. Yapılan incelemede fikir ve ifade hürriyetinin insanın doğuştan getirdiği temel haklar kapsamında değerlendirilmesi gerektiği ve yapıcı muhalefetin de oto kontrol mekanizması için önemli olduğu vurgulanmıştır. Bu bağlamda Hz. Peygamber'in önemli olaylar öncesinde sahâbîlere duygu ve düşüncelerini sorduğu, kendi görüşüne aykırı olsa bile çoğunluğun görüşüne uyduğu ve verdiği kararlara muhalefet edenleri de büyük bir olgunlukla karşıladığı sonucuna ulaşılmıştır.

Anahtar Kelimeler: Hz. Peygamber, fikir özgürlüğü, ifade hürriyeti, muhalefet, sahâbe.

\section{Giriş}

İnsanın şerefli bir varlık olduğunu bildiren Kur'ân-1 Kerim, insanın aklını en iyi şekilde kullanmasını önermektedir. Allah, insanın aklını en iyi şekilde kullanması için tezekkür, tedebbür, teakkul, tefakkuh ve tefekkür gibi kavramlara vurgu yapmaktadır. Bu kullanımlar, bizlere, Allah'ın konuya ne kadar önem verdiğini göstermektedir. Allah'ın bu kadar önem verdiği konuya Müslümanlar ne kadar değer vermektedirler ve hayatlarına onu ne kadar uygulamaktadırlar. Toplumların dinamik olması, insanlararası ilişkilerin canlı tutulması ve insanların birbirlerini sağlıklı bir şekilde kontrol edebilmeleri için aklın ve aklî melekelerin zinde kalması gerekmektedir. Hakkı ve hakikati daha iyi anlayabilmek, yapılan davranışların doğruluğunu ve yanlışlığını görebilmek, ortaya çıkan sorunları çözebilmek, batıl inanç ve inanışlardan uzak durabilmek, tutarlı ve mantıklı bir inanç yapısına sahip olabilmek ve yaşanılan hayatı anlamlandırabilmek için aklın aktif bir şekilde kullanılması gerekmektedir. Bu sebeple insanlar, Allah'ın kendilerine verdiği bu aklı, bütün yaşamlarını kapsayacak şekilde dinamik olarak kullanmalı ve pasif olmaktan da uzak durmalıdır.

İnsanların doğuştan sahip olunan canı, malı, dini, nesli ve aklı koruma gibi temel hak ve hürriyetleri bulunmaktadır. Bu temel hak ve hürriyetler içerisinde canı ve aklı koruma ön planda gelmektedir. Çünkü insanı insan yapan akıl, korunmadığı zaman diğer özgürlüklerin de bir anlamı bulunmamaktadır. Dolayısıyla insan, şahsiyeti ve onuru uğruna aklın kullanılmasının önündeki engellerin kaldırılması için bütün benliğiyle çalışmalıdır. Burada aklın kullanılmasıyla ilgili kastettiğim nokta; fikir, ifade ve düşünce özgürlügünün yanında sorgulama, araştırma, inceleme ve eleştiri 
yapabilmenin önündeki engellerin kaldırlmasıdır. Bu bağlamda İslâm dünyasında itaat kültürü yaygin olduğundan sorgulamaya ve eleştirmeye pek sıcak bakılmamaktadır. Halbuki bu yetilerin bir toplum içerisinde yaygin olması, o toplum bireylerinin ne kadar dinamik ve zinde olduklarını göstermektedir. Şunu açık yüreklilikle ifade etmeliyim ki, Müslüman toplumlarda aklı kullanma, sorgulama, eleştirme, fikir, ifade ve düşünce hürriyeti, diğer toplumlardan daha çok olmalıdır. Çünkü gerek Kur'ân'da gerekse de Hz. Peygamber'in uygulamalarında aklın kullanılması ve olaylara eleştirel bir bakış açısıyla yaklaşılması istenmektedir. Kur'ân-1 Kerim iyi bir şekilde okunur ve Hz. Peygamber'in örnek hayatı tedkik edilirse, konunun ne kadar önemli olduğu anlaşılacaktır. Konu hakkında Allah, Kur'ân'da şöyle buyurmaktadır: "Andolsun biz, cinler ve insanlardan, kalpleri olup da bunlarla anlamayan, gözleri olup da bunlarla görmeyen, kulakları olup da bunlarla işitmeyen birçoklarını cehennem için var ettik. İşte bunlar hayvanlar gibi, hatta daha da aşağıdadırlar. İşte bunlar gafillerin ta kendileridir." 1 "Şüphesiz, yeryüzünde yürüyen canlıların Allah katında en kötüsü, akıllarını kullanmayan sağırlar, dilsizlerdir."2, "Allah'ın izni olmadıkça, hiçbir kimse iman edemez. Allah azabı akılların (güzelce) kullanmayanlara verir."’3 Bu âyetlerde kullanılan ifadeler oldukça ağırdır. Bu sebeple Müslümanlar, kendilerine verilen akıl nimetinin değerini bilip ona göre hareket etmelidirler. Bu hususta herkes üzerine düşen görevi en etkili bir şekilde yerine getirerek özgür bir ortamın oluşmasına katkı sağlamalıdır. Bu çalışma, Hz. Peygamber döneminde fikir ve ifade hürriyetinin nasıl oluşturulduğunu ve muhalefet edenlere olgunlukla nasıl yaklaşıldığını ortaya koymayı hedeflemektedir.

\section{Hz. Peygamber Döneminde Fikir ve İfade Hürriyeti}

\section{A. Bedir Savaşı}

Hz. Peygamber, Mekkelilere ait olan kervanın Suriye'den döneceği haberini alınca, arkadaşlarıyla görüştükten sonra kervandaki malları ele geçirmek için harekete geçti. Kervanı ele geçirmek üzere Hz. Peygamber'in Medine'den bir grupla yola çıktığını haber alan Ebû Süfyân hem kervanın kurtarılması için Mekke'ye haber göndermiş hem de yol güzergâhını değiştirmiştir. Kervanın tehlikede olduğu haberini alan Mekkeliler mallarını kurtarmak için harekete geçtiler.

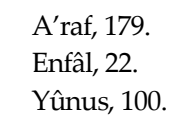


Ancak Ebû Süfyân kervanın güvenlikte olduğu haberini göndermesine rağmen Ebû Cehil'in: "Çıktıkları bu yoldan savaşmadan ve Araplar'a üstünlüklerini kantlamadan dönmeyeceklerini" belirtmesi, savaş ihtimalinin ortaya çıktığını göstermektedir. Müslümanlar kervanın kurtulduğunu ve Mekke'den savaşmak üzere bir ordunun üzerlerine doğru geldiğini haber alınca, Hz. Peygamber yeni gelişen bu durum karşısında durum değerlendirmesi yapmak için arkadaşlarının görüşlerini öğrendikten sonra karar vermenin daha doğru olacağını düşündü. Bu amaçla o, arkadaşlarının konu hakkındaki görüşlerini sormaya başladı. Hz. Ebû Bekir ve Hz. Ömer görüşlerini belirttikten sonra Mikdâd ayağa kalkarak: “Ey Allah'ın Rasûlü! Allah'ın emrettiği yolda devam et, bizler sana tabiyiz. Bizler, İsrailoğullarının Musa'ya dediği gibi sana: “Sen, Rabbin ile birlikte savaşa git, bizler burada bekleyeceğiz, demeyiz. Bizler, sen nereye gidersen, oraya gideriz" diyerek görüşlerini belirtti. Daha sonra Hz. Peygamber, ensârın kendilerini Medine içerisinde korumaya söz verdiklerini düşünerek: "Sizler de görüşlerinizi belirtiniz" dedi. Bunun üzerine ensârdan Sa'd b. Muâz: "Ey Allah'ın Rasûlü! Bizleri mi kastediyorsun? dedi. Allah Rasûlü'nden: "Evet" cevabını alın Sa'd: "Ey Allah'ın Rasûlü! Bizler sana inandık, Allah'tan getirdiklerini kabul ettik ve sana tâbi olduk. Artık siz ne emrederseniz onu yapmaya hazırız. Eğer sen, denize girersen, bizler de seninle beraber oraya gireriz ve hiç birimiz de geri kalmayız. Düşmanla karşılaşmaktan korkmayız. Savaş esnasında geri dönmeyiz, sabrederiz ve sadakatten ayrılmayız" diyerek görüşlerini belirtti. ${ }^{4}$

Böylece Hz. Peygamber, sahâbîlerin olumlu görüş belirtmesi üzerine savaş karar aldı. Hz. Muhammed hem bir peygamber hem devlet başkanı hem de ordu komutanı olmasına rağmen önemli bir savaş öncesi arkadaşlarının görüşlerini sorması, onun olduğu toplumda fikir ve ifade hürriyetinin ne kadar önemli olduğunu ortaya koymaktadır. O, bulunduğu konum itibariyle insanlara fikirlerini sormaya gerek duymadan da savaş kararı alabilirdi. Muhtemelen onun alacağ 1 herhangi bir karara itiraz eden de olmayabilirdi. Ancak o, toplumun geleceğini ilgilendiren bir olayda tek başına karar almanın doğru olmayacağının, ortak aklı harekete geçirmenin daha

4 İbn Hişâm, Abdülmelik, es-Sîretü'n-Nebeviyye, Dâru İbn Kesîr, Kahire ts., I-II, 606615; Terî, Ebû Ca' fer Muhammed b. Cerîr, Târîhu'l-Ümem ve'l-Mülûk, Dâru'l-Kütübi'l-Ilmiyye, Babeyrut 1997, II, 20-27; İbnü'1-Esîr, Izzüddin Ebi'l-Hasen Ali b. Ebi'l-Keram, el-Kâmil fi't-Târîh, Dâru Sâdır, Beyrut 1979, II, 116-120; İbn Kesîr, Ebu'l-Fidâ İsmail, el-Bidâye ve'n-Nihâye, Dâru'l-Hadîs, Kahire 1994, III, 292-298. 
sağlıklı neticeler vereceğinin ve başarının da toplumun ortak hareket etmesiyle mümkün olacağının idrakindeydi. Çünkü duygu ve düşüncelerine saygı gösterilen insanlar aidiyet duygusunu yakından hissederek moral ve motivasyonlarını üst seviyede tutmaya çalıştıkları bilinmektedir.

\section{B. Bedir Esirleri}

Mekke döneminde müslümanlar ezildiği, baskıya uğradığı, hayat hakkı olmadığı, din ve vicdan özgürlükleri ellerinden alındığından dolayı 622 tarihinde Medine'ye hicret etmek zorunda kalmışlardır. Medine, müslümanlar için yeni bir dönemin başlangıcıdd. Artık burada Mekke'de olan olumsuz şartlar yoktu ve onlar yeni bir devlet kurduklarından dolayı kendilerine yapılacak olan menfi davranışlara karşı koyma gücüne sahip oldular. Gerek seriyyeler gerekse de bazı münferit olaylarla kendi güçlerini hissettirmeye başladılar. Artık Mekke site devleti, Batn-1 Nahle olayında Müslümanlar kendilerine karşı koyabilecek bir güce ulaştıklarını hissetmeye başladılar. Ebû Süfyan'ın başkanlığındaki Mekke ticaret kervanının Şam'dan dönerken Müslümanlar tarafından ele geçirilmeye çalışılması, Mekkelileri gerçekten çileden çıkarmış ve kervanı kurtarmak amacıyla harekete geçmişlerdi. Bu amaçla hak ile batılın mücadelesi olarak bilinen Bedir Savaşı 624 tarihinde gerçekleşti. Müslümanların zaferiyle sonuçlanan Bedir Savaşı'nda Mekkeli müşriklerden 70 kişi öldürülürken, müslümanlardan da 14 kişi şehit düşmüştür. Ayrıca müşriklerden 70 esir alınmıştı. Bu esirlerden Mekke döneminde müslümanlara baskı yapanların başında gelen Nadr b. Hâris ve Ukbe b. Ebî Muayt ${ }^{5}$ yolda Hz. Peygamber'in emriyle öldürüldüler. ${ }^{6}$ Allah Rasûlü, dünyevî hususlarda halkı ilgilendiren konularda karar vermeden önce "Onların işleri aralarında şûrâ iledir"7 ve "İşs konusunda onlarla istişare et"s âyetleri bağlamında toplumun düşüncelerine değer vererek onlarla istişarede bulunurdu. Bu amaçla o, 68 esire uygulanacak metod konusunda ashâbiyla istişarede bulunarak Hz. Ebû Bekir'e görüşünü sordu.

5 İbn Hişâm, es-Sîratü'n-Nebeviyye, I-II, 644; Hudarî Bey, Muhammed, Nûru'l-Yakîn fi Sirrati Seyyidi'l-Mürselîn, Dâru'l-Hadîs, Mısır 1992, s. 177.

6 İbn Hişâm, es-Sîratü'n-Nebeviyye, I-II, 644; Taberî, Târîhu'l-Ümem, II, 39; Süheylî, Abdurrahman, er-Ravdu'l-Unuf, Dâru'l-Fikr, Beyrut ts, V, 153; Hudarî Bey, Nûru'l-Yakîn, s. 177.

7 Şûrâ, 38.

8 Âl-i İmrân, 59. 
Hz. Peygamber Döneminde Düşünce Özgürlüğü ve Muhalefet

Hz. Ebû Bekir: "Ey Allah'ın Rasûlü! Allah onları helak etti ve seni muzaffer kıldı. ${ }^{9}$ Bunlar aşiretin ve amcaoğullarındır. Onlardan fidye alınmasını uygun görüyorum. Çünkü alınan bu fidyeler, kâfirlere karşı bizi güçlü duruma getirir. Belki Allah onlara hidayet verir de bize destek olurlar" şeklinde görüş bildirdi. Daha sonra Hz. Peygamber: “Ey Hattab'ın oğlu görüşün nedir?" diye sorduğunda Hz. Ömer: "Ya Rasûlallah, ben, Ebû Bekir'in düşündüğü gibi düşünmüyorum. Onlar kâfirlerin liderleri ve elebaşları, seni memleketinden çıkaran düşmanlarındır. İzin ver, boyunlarını vuralım. Bu amaçla Ali b. Ebî Tâlib kardeşi Akîl b. Ebî Tâlib’in, Hamza b. Abdilmüttalib kardeşi Abbâs b. Abdilmuttalib'in boynunu vursun. Böylece insanlar, kalbimizde kâfirlere karşı bir meylimizin olmadığını anlasınlar."10 Hatta o, Kureyş'in hatibi olan ve Bedir esirleri arasında bulunan Süheyl b. Amr hakkında: "Ya Rasûlallah! Beni bırak, onun ön dişlerinden ikisini sökeyim de, bir daha hiçbir yerde senin aleyhine konuşmaya kalkışmasın" dedi. Hz. Peygamber: "Ben dişlerini söktürerek ona işkence yapamam. Ona bu şekilde muamele yaparsam, Peygamber olsam bile, Allah da bana aynı şekilde muamele eder"11 diyerek Hz. Ömer'in teklifini geri çevirdi. İnsanlara verilecek en büyük ceza, onların size karşı yaptıkları olumsuz davranışları karşısında sizin onlar gibi davranmamanızdır. Bu açıdan Hz. Peygamber'in Süheyl b. Amr'a karşı bu tavrı, esirlere iyi muamelede bulunması, onlara işkenceye izin vermemesi, düşmanı İslâm'a kazandırmayı ve kendisinden yeri geldiğinde istifade etmeyi amaçlaması, onun hayatı boyunca İslâmî tebliğde güttüğü siyasetin en güzel örneklerinden birini oluşturmaktadır. Hz. Peygamber: "Abdullah b. Revâha'ya görüşün nedir?" diye sordu. Abdullah b. Revâha: "Ya Rasûlallah, onları ateşte yakalım" dedi. Bunun üzerine Abbâs b. Abdilmuttalib: "Ne kadar acımasızsın!" dedi. Bu karşılıklı konuşma karşısında Allah Rasûlü

$9 \quad$ Hudarî Bey, Nûru'l-Yakîn, s. 181.

10 Müslim, Ebu'l-Hüseyin Müslim b. Haccâc, Sahîhu Müslim, Çağrı Yayınları, İstanbul 1992 Cihad, 58; Taberî, Târîhu'l-Ümem, II, 46; Beyhakî, Ebû Bekir Ahmed b. Hüseyin, Delâilü'n-Nübüvve, Dâru'l-Kütübi'l-Ilmiyye, Beyrut 1988, III, 138; İbnü'l-Esîr, el-Kâmil, II, 136; İbn Kesîr, el-Bidâye , III, 331-332; Diyârbekrî, Hüseyin b. Muhammed b. Hasan, Târîhu'l-Hamîs fì Ahvâli Enfesi Nefiss, Dâru'l-Kütübi'l-Ilmiyye, Beyrut 1971, II, 132; Hudarî Bey, Nûru'l-Yakîn, s. 181; Gazâlî, Muhammed, Fıkhu's-Sîre, Dâru'l-Kalem, Beyrut 1994, s. 236; Rızâ, Muhammed, Muhammed, Dâru'l-Kalem, Beyrut 2003, s. 191-192.

11 İbn Hişâm, es-Sîratü'n-Nebeviyye, I-II, 649; Taberî, Târîhu'l-Ümem, II, 41. 
sessiz kaldı.12 Hz. Peygamber aynı soruyu Sa'd b. Muaz'a sordu. Sa'd b. Muaz: "Bana, onların kökünü kazımak, onları yeryüzünde sağ birakmaktan daha sevimli gelir" diye cevap verdi. ${ }^{13}$

Sahâbîler, ileriye sürülen bu görüşler etrafında kendilerine uygun olanı tartı̧̧maya başladılar. ${ }^{14}$ Onların gruplara ayrıldığını gören $\mathrm{Hz}$. Peygamber: "Bunlar neye benzer bilir misiniz?" dedi. Allah, bazılarının kalbini sütten daha yumuşak yaparken, bazılarının kalbini de taştan daha sert yapmıştır. Ey Ebû Bekir, sen: "Ya Rabbi! Kavmim içinden bana katılanlar, bendendir, bana karşı asi olanlara gelince; sen çok bağışlayan ve merhamet edensin" 15 diyen İbrahim'e ve: “Eğer onlara azap edersen, şüphe yok ki onlar senin kullarındır. Eğer onları bağışlarsan, yine şüphe yok ki, sen mutlak güç sahibisin, hüküm ve hikmet sahibisin"16 diyen Hz. İsa'ya benzemektesin. Ey Ömer sen de: “Ey Rabbim! Kâfirlerden hiç kimseyi yeryüzünde bırakma!"17 diyen Hz. Nuh'a ve: “Ey Rabbim! Sen onların malların silip süpür ve kalplerine darlık ver, çünkü onlar elem dolu azabı görünceye kadar iman etmezler"18 diyen Musa'ya benzemektesin. ${ }^{19}$ İbn Kesîr'in rivayetinde Abdullah b. Revâha ise; yukarıdaki âyet zikredilerek Hz. Musa'ya benzetilmektedir. ${ }^{20}$ Ayrıca Taberî ve Diyârbekrî́nin rivayetlerinde Hz. Peygamber: "Sizler bugün muhtaçsınız. Onlar ise ancak, fidye vermekle veya öldürülmekle serbest kalırlar"21 buyurarak fidye alınmasından yana bir izlenim uyandırmaktadır.

Esirlerin durumu hakkında ortaya çıkan fidye ve öldürme görüşleri içerisinde Hz. Peygamber, Hz. Ebû Bekir'in ileri sürdüğü

12 Taberî, Târîhu'l-Ümem, II, 46; İbn Kesîr, el-Bidâye , III, 332; Diyârbekrî, Târîhu'l-Hamîs, II, 132; Rızâ, Muhammed, s. 192.

13 Rizâ, Muhammed, s. 192.

14 Taberî, Târîhu'l-Ümem, II, 46; İbn Kesîr, el-Bidâye, III, 332.

15 İbrahim, 36.

16 Mâide, 118.

17 Nuh, 26.

18 Yunus, 88.

19 Taberî, Târîhu'l-Ümem, II, 46; Beyhakî, Delâilü'n-Nübüvve, III, 138-139; İbn Kesîr, elBidâye, III, 332; Diyârbekrî, Târîhu'l-Hamîs, II, 132; Hudarî Bey, Nûru'l-Yakîn, s. 181.

20 İbn Kesîr, el-Bidâye , III, 332.

21 Taberî, Târîhu'l-Ümem, II, 47; Diyârbekrî, Târîhu'l-Hamîs, II, 133. 
esirlerden fidye alınması teklifini benimsedi. ${ }^{22}$ Ancak kısa bir süre sonra Hz. Peygamber'in bu uygulamasını kınayan âyetler nazil oldu..$^{23}$

Rasûlullah'ın, Bedir Savaşı'nda esir alınan kişilere nasıl muamele edileceğini toplumla müzakere ettikten sonra karara bağlaması, toplumsal olaylarda onun ne kadar fikir ve ifade hürriyetine önem verdiğini göstermektedir. Ayrıca esir alınan kişiler arasında Müslümanların da yakın akrabaları bulumaktaydı. Bu sebeple Allah Rasûlü, uygulanacak muamele konusunda arkadaşlarının görüşlerini alarak onları da karar alma mekanizmasına dâhil etmiştir. Hz. Peygamber bu uygulamasıyla insanların düşünce özgürlüğüne, fikir ve ifade hürriyetine saygılı davranarak onların, kendilerini gerçekleştirmelerine zemin hazırlamıştır. İdareciler, düşünce özgürlüğünün önündeki engelleri kaldırdıkları oranda insanın özüne nüfûz ederek gelişmelerine katkıda bulunurlar. Toplumların gelişmesi ve kalkınması da ancak bu sayede mümkündür. Bu sebeple $\mathrm{Hz}$. Peygamber örnek alınırken düşünce özgürlüğüne, fikir ve ifade hürriyetine verdiği değer önemsenmelidir.

\section{C. İfk Olayı}

627 yılında yapılan ve Müslümanların zaferiyle sonuçlanan Benî Mustalık (Mureysî) savaşı dönüşünde ordunun konakladığı esnada ensâr ve muhâcirûn arasında meydana gelen bir olaydan²4 dolayı Hz. Peygamber, orduya hemen hareket etmesini bildirdi. Ordu acele bir şekilde hareket ettiğinden ve o esnada bir ihtiyaçtan dolayı karargahın uzağında olan Hz. Aişe'nin, hevdecinde olup olmadığı

22 Taberî, Târîhu'l-Ümem, II, 47; Beyhakî, Delâilü'n-Nübüvve, III, 139; İbn Kesîr, el-Bidâye, III, 333; Diyârbekrî, Târîhu'l-Hamîs, II, 133; Hudarî Bey, Nûru'l-Yakîn, s. 181; Ğazâlî, Fıkhu's-Sîre, s. 236; Rızâ, Muhammed, s. 192.

23 "Yeryüzünde düşmanı tamamıyla sindirip hakim duruma gelmedikçe, hiçbir Peygamber'e esir almak yakışmaz. Siz geçici dünya menfaatini istiyorsunuz, halbuki Allah ahireti istiyor. Allah mutlak güç sahibidir, hüküm ve hikmet sahibidir. Ĕ̆gr Allah'ın daha önce verilmiş bir hükmü olmasaydı, aldığınız şeyden dolayı size büyük bir azap dokunurdu."' Enfâl, 67-68.

24 Ayrıntılı bilgi için bk. Buhârî, Ebû Abdullah Muhammed b. İsmail, Sahîhu'l-Buhârî, Çağrı Yayınları, İstanbul 1992, Tefsîru Sûrati'l-Münâfikîn, 1-2; İbn Hişâm, es-Sîratü'nNebeviyye, III-IV, 29; Münâfikûn, 8; Vâkıdî, Muhammed b. Ömer, Kitâbü'l-Meğââ̂, Dâru'l-Fikr, Beyrut 1984, I, 404-413, II, 415-426; İbn Hişâm, es-Sîratü'n-Nebeviyye, IIIIV, 289-291; İbn Sa'd, Muhammed, et-Tabakâtü'l-Kübrâ, Dâru'l-Kütübi'l-Ilmiyye, Beyrut 1990, II, 48-50; Taberî, Târîhu'l-Ümemve'l-Mülûk, II, 109; İbnü'l-Esîr, el-Kâmil, II, 192-193; İbn Kesîr, el-Bidâye, IV, 157-158; Diyârbekrî, Târîhu'l-Hamîs, II, 275-276; Hudarî Bey, Nûru'l-Yakîn, s. 231-235; Rizâ, Muhammed, ss. 243-244. 
farkedilememişti. Hz. Aişe, karargaha geldiğinde hiç kimseyi göremedi. Hevdecde olmadığı farkedilir düşüncesiyle beklemeye başladı. Hz. Pergamber ordunun arkasını kontrol etmek amacıyla Safvân b. Muattal'1 görevlendirdi. Safvân b. Muattal beklemekte olan Hz. Aişe'yi tanıyınca devesine binmesini söyledi. Safvân b. Muattal devenin yularını tutarak hızlı bir şekilde orduya yetişmeye çalıştı. Fakat orduya yetişemeyip, geceyi yolda geçirdiler ve sabahleyin karargaha vardilar. ${ }^{25}$

Hz. Aişe ve Safvân b. Muattal'ın karargaha geç katılmasını fırsat bilen münafıkların lideri olan Abdullah $b$. Ubey $b$. Selûl ve diğer münafiklar Hz. Aişe ve Safvân b. Muattal aleyhinde konuşmaya başladılar. Hz. Aişe Medine'ye gelince hastalandı. Fakat, kendisi hakkında söylenenlerden haberi olmamasına rağmen, $\mathrm{Hz}$. Peygamber'in kendisine karşı tavırlarında bazı değişiklikler olduğunu hissediyordu. $\mathrm{O}$, kendisine diğer hastalıklarında gösterdiği sevgi ve şefkati göstermiyordu. Odaya gelir ve tedavi edenlere: "Bugün hepiniz nasılsınız?" der, onu da diğerlerinin arasına katardı. Buna çok üzülen $\mathrm{Hz}$. Aişe, annesinin evine gidip orada tedavi olmak için $\mathrm{Hz}$. Peygamber'den izin istedi. Hz. Peygamber de: "Nasıl istersen” dedi. ${ }^{26}$

Hz. Aişe olup bitenleri Mistah b. Üsâse'nin annesinden öğrenince çok üzüldü. Hz. Peygamber, Abdullah b. Ubey b. Selûl, Hassân b. Sâbit, Mistah b. Üsâse ve Hamne bt. Cahş'ın iftira kampanyalarından çok rahatsız oldu ve olayın doğruluğunu araştırmak için bazı Müslümanların görüşlerine müracaat etti. ${ }^{27}$

Üsâme b. Zeyd: "Biz, Aişe hakkında iyilikten başka bir şey bilmiyoruz." Ali b. Ebî Tâlib: "Allah seni sınırlamadı. Onun dışında

25 Vâkıdî, Kitâbü'l-Meğâzî, II, 404-413, II, 426-429; İbn Hişâm, es-Sîratü'n-Nebeviyye, III-IV, 297-298; İbn Sa'd, et-Tabakâtü'l-Kübrâ, II, 50; Taberî, Târîhu'l-Ümemve'l-Mülûk, II, 111112; İbnü'l-Esîr, el-Kâmil, II, 195-196; İbn Kesîr, el-Bidâye, IV, 161; Diyârbekrî, Târîhu'lHamîs, II, 284-285; Hudarî Bey, Nûru'l-Yakîn, s. 236; Rızâ, Muhammed, s. 246.

26 Vâkıdî, Kitâbü'l-Meğâzî, II, 428-429, II, 426-429; İbn Hişâm, es-Sîratü'n-Nebeviyye, IIIIV, 298-299; İbnü'l-Esîr, el-Kâmil, II, 196; İbn Kesîr, el-Bidâye, IV, 161-162; Diyârbekrî, Târîhu'l-Hamîs, II, 287; Hudarî Bey, Nûru'l-Yakîn, s. 236.

27 Vâkıdî, Kitâbü'l-Meğââî, II, 430; İ̉n Hişâm, es-Sîratü'n-Nebeviyye, III-IV, 300-301; Taben̂̂, Târîhu'l-Ümemve'l-Mülûk, II, 113; İbnü'l-Esîr, el-Kâmil, II, 197; İbn Kesîr, elBidâye, IV, 162; Diyârbekrî, Târîhu'l-Hamîs, II, 287; Hudarî Bey, Nûru'l-Yakîn, s. 237; Geniş bilgi için bk. Aksu, Ali, "Iffk Olayı Üzerine Değerlendirme”, Cumhuriyet Üniversitesi Illahiyat Fakültesi Dergisi, Sivas 2004: VIII/1, 1-21; Kara, Seyfullah, "İfk Olayının Etkileri ve Olayla ilgili Ortaya Konan Tavırlar", Atattürk Üniversitesi Illahiyat Fakültesi, Erzurum 2001, XV, 343-382. 
pek çok kadın var. Cariyeye sor, o sana doğruyu söyler"dedi. Bunun üzerine Hz. Peygamber, Berîre'ye haber gönderdi ve: “Ey Berîre! Şimdiye kadar Aişe'de, ondan şüphelenmeni gerektirecek bir hareket gördün mü?" Berîre bu soruya şöyle cevap verdi: "Seni hak ile gönderene yemin olsun ki, onda iyilikten başka bir şey bilmiyorum. $\mathrm{O}$ henüz küçük genç bir kız. Onda gördüğüm tek kusur, uyarmama rağmen yoğurduğum hamuru uyuya kalarak kuzuya yedirmesidir"'28 Ayrıca Hz. Peygamber, Zeyneb bt. Cahş ve Ümmü Eymen'e de konu hakkında görüşlerini sorunca onlar: "Biz de onun hakkında iyilikten başka bir şey bilmiyoruz" dediler.29

Hz. Peygamber ayn gün durum değerlendirmesi yaptıktan sonra mescidde insanlara hutbe irad ederek şöyle dedi: "Ey insanlar, ailem hakkında doğru olmayan şeyleri söyleyerek beni inciten kişiler için ne dersiniz? Ben, ailem hakkında iyilikten başka bir şey bilmiyorum. $\mathrm{O}$ adam, yanında ben olmadıkça evlerimden hiç birine girmezdi." Bu konuşmadan sonra Üseyd b. Hudayr ayağa kalkarak: "Ya Rasûlallah! Senden özür diliyorum. Söylediklerin Evs kabilesinden ise, onlara hadlerini bildiririz. (onları öldürürüz.) Hazrec kabilesinden iseler emret, onlara da aynısını yapalım." Bunun üzerine Sa'd b. Ubâde: "Sen onları öldüremezsin ve öldürmeye de gücün yetmez. Çünkü onlar senin kabilenden olsaydı, öldürmeye bu kadar istekli olmazdın" dedi. Üseyd b. Hudayr, Sa'd'ın bu sözlerine karşılık: "Söylediklerine katılmıyorum. Elbette onları öldüreceğiz. Sen münafıkların tarafını tutuyorsun" diyerek karşılık verince ortalık gerginleşti, iki kabile birbirine girmek üzereyken Hz. Peygamber'in araya girmesiyle durum sakinleşti. ${ }^{30}$

Hz. Aişe ailesinin yanındayken bu olaydan dolayı sürekli ağladığını, göz yaşlarının kesilmediğini, bir an bile uyuyamadığını, hatta ağlamaktan ciğerlerinin parçalanacağını, anne ve babasının yanında sabahladıklarını, o esnada Ensârdan bir kadının yanına geldiğini, kendisiyle ağlamaya başladığını, bu haldeyken $\mathrm{Hz}$.

28 Vâkıdî, Kitâbü'l-Meğâzî, II, 430; İbn Hişâm, es-Sîratü'n-Nebeviyye, III-IV, 301; Taberî, Târîhu'l-Ümem, II, 113; İbnü'l-Esîr, el-Kâmil, II, 197; İbn Kesîr, el-Bidâye , IV, ss. 162-163; Diyârbekrî, Târîhu'l-Hamîs,, II, 287; Hudarî Bey, Nûru'l-Yakîn, s. 237; Gazâlî, Fıkhu'sSîre, s. 290; Rızâ, Muhammed, 246-247.

29 Vâkıdî, Kitâbü'l-Meğâzî, II, 430-431.

30 Vâkıdî, Kitâbü'l-Meğâzî, II, 431; İbn Hişâm, es-Sîratü'n-Nebeviyye, III-IV, 300-301; Taberî, Târîhu'l-Ümemve'l-Mülûk, II, 113; İbnü'l-Esîr, el-Kâmil, II, 197; İbn Kesîr, elBidâye , IV, 162; Hudarî Bey, Nûru'l-Yakîn, s. 238; Ğazâlî, Fıkhu's-Sîre, s. 291; Rıâ, Muhammed, 248-249. 
Peygamber'in kendisini ziyarete geldiğini ve kendisine: "Ey Aişe, senin hakkında bana bazı şeyler ulaştı. Eğer masumsan, Allah masum olduğunu açıklar. Eğer yasak olan şeyi yaptıysan, Allah'tan bağışlanma dile ve O'na tevbe et. Kul, hatasını itiraf edip tevbe ederse, Allah ona merhamet eder" sözlerini işitince çok üzüldüğünü, babasının ve annesinin ona cevap vermesini istediğini, fakat onlara söyleyecek bir şey bulamayınca, kendisi: "İnsanların benim hakkımda söylediklerini duyduğunuzu ve onların sizin kalbinizde yerleşip, onlara inandığınızı biliyorum. Size masum olduğumu söylesem-Allah benim masum olduğumu biliyor- bana inanmayacaksınız. Fakat, Allah'ın masum olduğumu bildiği şeyi yaptığımı itiraf edersem, beni tasdik edersiniz. Fakat ben, Yusuf'un babasının dediği gibi: "Bundan sonra bana düşen, güzel bir sabırdır. Anlattıklarınıza karşı yardımı istenilecek de ancak Allah'tır"31 diyeceğim, dedi ve yatağına gitti. Devamında Hz. Aişe: “O anda suçsuz olduğumu bildiğim için Allah'ın da suçsuzluğumu ilan edeceğine inanıyordum. Fakat Kur'ân'dan bir âyet indirerek beni temize çıkaracağını tahmin etmemiştim. Yine de Allah'ın suçsuz olduğumu bir rüya ile Hz. Peygamber'e bildirmesini bekliyordum. Allah Rasûlü'nde vahiy gelme hali belirdi. O, elbisesiyle örtüldü. Başının altına deriden bir yastık konuldu. Ben, onun başından geçenleri görünce çok korkmadım ve dikkate de almadım. Suçsuz olduğumu bildiğim için içim rahatt. Allah zalim değildir. Anne ve babama gelince, Rasûlullah rahatlar rahatlamaz ailemin, Allah tarafından insanların dediği şeylerin doğru çıkacağı endişesiyle korkudan öleceklerini zannettim. $\mathrm{O}$, kendisine gelince oturdu. Ondan, kış gününde inci tanesi gibi ter akıyordu. $\mathrm{O}$, yüzündeki terleri silmeye başladı. Rasûlullah henüz yanımdan ayrılmamış ve ailemden hiç kimse dışarıya çıkmamıştı ki, Allah, suçsuzluğumu bildiren âyetleri indirmeye başladı. ${ }^{32}$ Rasûlullah'ın yüzü her vahy inişinde olduğu gibi aydınlanmıştı. Bana söylediği ilk söz: “Ey Aişe, Allah'a hamd et. O, seni temize çıkardı" demek oldu. Bunun üzerine annem benden Rasûlullah'a teşekkür etmemi istedi. Ancak ben: "Hayır! Vallahi suçsuzluğumu Allah bildirdiği için O'ndan başka kimseye hamd etmem" dedim. ${ }^{33}$ 
Medine toplumunun bir ay süresince İfk Olayı ile meşgul olması, doğal olarak Allah Rasûlü'nü derinden yaralamıştır. Onun en yakınlarıyla istişarede bulunması, olayın tesiri altında kaldığının bir göstergesidir. Hz. Peygamber olayı duyduğu zaman Hz. Aişe'nin en yakınlarından olan kişlerle konuyu konuştuktan sonra halk ile istişare etmesi, onun olayı ne kadar derinlemesine araştırdığını ve en ince noktaları dikkate aldığını göstermektedir. Allah Rasûlü bu araştırmayı yaparken ön yarglı davranmamakta ve kişileri yönlendirmemektedir. Sahâbîler de Hz. Aişe hakkında düşündüklerini objektif bir şekilde ifade etmeye çalışmaktadırlar. Onların Hz. Peygamber'e olan sevgi ve bağlılıkları, kendilerini olay hakkında aşırılığa sevketmemektedir. Gerçekten Hz. Peygamber bu hadisede büyük bir iftira ile karşı karşıya kalmış hem kendine hakim olmuş hem de ortaya çıkan krizi en iyi şekilde yönetmiştir. Olay sonuçlanıncaya kadar Hz. Peygamber, ne Hz. Aişe'ye ne Safvân b. Muattal'a ne de ne de iftira kampanyasını yürütenlere olumsuz bir şey söylemiştir. Allah Rasûlü'nün olayın aydınlığa kavuşturulması için en yakınlarından başlayarak insanlara görüşlerini sorması ve bu görüşler doğrultusunda bir hareket tarzı belirlemesi, fikir ve ifade hürriyetinin lider üzerinde ne kadar etkili olduğunu göstermektedir. Konu hakkında görüşüne başvurulanlar, Hz. Âişe'nin masumiyeti hakkında fikir beyanında bulundukları için Hz. Peygamber olayın çözümümnü zamana bırakmıştır. Eğer görüşüne başvurulanlar Hz. Âişe hakkında iftira kampanyası doğrultusunda açıklamalarda bulunsalardı, Rasûlullah'ın tavrı daha farklı olabilirdi. Bu sebeple insanların duygu ve düşüncelerini bu kadar rahat bir şekilde ifade etmeleri, Hz. Peygamber'in onlara sunmuş olduğu özgür ortamdan dolayıdır.

\section{Uhud Savaşı}

Hz. Peygamber 625 yılında amcası Abbâs b. Abdülmuttalib vasıtasıyla $^{34}$ Mekke'den büyük bir ordunun Medine üzerine doğru gelmekte olduğu haberini alınca savaşın nasıl yapılması gerektiği konusunu görüşmek üzere ensâr ve muhâcirîni istişare etmeye çağırdı. Rasûlullah Medine içerisinde kalınarak savunma savaşı yapılması konusundaki fikrini belirtti. Ancak Bedir Savaşı'na katılamayan gençler meydan savaşı yapılmasını teklif ettiler ve bu konuda da oldukça 1srarlı davrandılar. Bunun üzerine Allah Rasûlü

34 İbn Sa'd, et-Tabakâtü'l-Kübrâ, II, 28. 
savunma savaşı yapılması eğiliminde olmasına rağmen gençlerin fikri doğrultusunda meydan savaşı yapılmasına karar verdi ve savaş kıyafetlerini giymek üzere evine gitti. Sa'd b. Muaz ve Üseyd $b$. Hudayr gibi bazı sahâbîler Hz. Peygamber'e gelerek kendi fikrini uygulamasını belirttiler. Ancak İslâm Peygamber'i: “Bir Peygamber giydiği zırhını savaşmadan çıkarmaz. Eğer sabrederseniz, her biriniz görevinizi yaparsanız, Allah zaferi bize ihsan edecektir"35 diyerek gençlerin görüşünü onaylamış ve kendi görüşüne aykırı olmasına rağmen onların görüşlerini kabul ederek hem fikir ve ifade hürriyetine ne kadar önem verdiğini göstermiş hem de özgür bir ortamın nasıl oluşturulması gerektiğinin önemini vurgulamıştır. Ayrıca Rasûlullah dönemindeki gençlerin hiçbir baskı altında kalmadan düşüncelerini ortaya koymaları dikkate şayan bir durumdur. Allah Rasûlü'nün de onlara bu imkânı tanıması ve kendilerini böyle davranmaya teşvik etmesi, devlet başkanının gençleri önemsediğini gözler önüne sermektedir. Bu bağlamda özgür bir ortamın oluşmasına lider ve toplum bireylerinin kendi imkânları oranında katkı sağlamaları gerekmektedir. Çünkü düşünce özgürlüğü, fikir ve ifade hürriyeti, kişinin varlık sebebidir.

\section{E. Hendek Savaşı}

Hz. Peygamber istihbarat kanalları vasitasıyla Mekke'den daha önce olmadığı kadar kalabalık sayıda bir ordunun üzerlerine doğru geldiği haberini alınca, arkadaşlarıyla durum değerlendirmesi yapmaya karar verdi. Bu çerçevede ortaya konulan görüşler içerisinden Selmân-1 Fârisî'nin teklifi olan, şehrin düşman saldırısına açık olan tarafların korumak amacıyla Medine' nin etrafına hendek kazılması fikri kabul edildi. Bu fikir doğrultusunda Hz. Peygamber bir grup sahâbe ile keşfe çıkarak kazılacak yerleri belirledi. Hendeğin kazılmasında ve savunulmasında üç bin Müslüman görev aldı. Her on kişilik takıma kırk zırâ'lık ${ }^{36}$ yer ayırdı. Kendisi kazı işine nezaret ettiği gibi bizzat çalıştı, toprak kazdı ve sırtında toprak taşıdı. Hendek, içine düşenin çıkamayacağı derinlikte ve karşıdan karşıya bir süvarinin atlayamayacağı genişlikte planlandı. Buna göre derinlik ve genişlik

35 İbn Hişâm, es-Sîratü'n-Nebeviyye, III-IV, 60, 63; İbn Sa'd, et-Tabakâtü'l-Kübrâ, II, 29;
Taberî, Târîhu'l-Ümem, II, 58-59; İbnü'l-Esîr, el-Kâmil, II, 148-150; İbn Kesîr, el-Bidâye,
III, 10-14.
36 Bir zirâ' yaklaşık 52 cm'dir. 
ölçüleri de tespit edildi. ${ }^{37}$ Hamidullah'ın tespitlerine göre hendeğin genişliği 5,5 km. uzunluğunda, $9 \mathrm{~m}$. genişliğinde ve $4.5 \mathrm{~m}$. derinliğindedir. ${ }^{38}$ Vâkıdî ve İbn Sa'd'a göre bu hendeğin kazımı altı günde tamamlanmıştır. ${ }^{39}$ Müslümanlar hem hendeğin düşman tarafından doldurulmasını önlemek ve hem de bu toprağı siper olarak kullanmak amacıyla kazıdan çıkan toprağı kendi taraflarına yı̆̆dılar. Ayrıca düşmana atmak için de kendi taraflarına taş yığdılar. Hendeğin kazılma işi tamamlandığında ise Medine sanki bir kale haline geldi. ${ }^{40} \mathrm{Bu}$ plan sayesinde Medine istilaya uğramaktan kurtulmuştur.

Hz. Peygamber ortaya çıkan krizin görüşülmesi ve alınacak kararda herkesin katkısının sağlanabilmesi amacıyla insanların kendisine yardımcı olmalarını istemiş ve konu hakkında nasıl bir uygulamanın kendileri için daha iyi sonuçlar vereceğini araştırmaya başlamıştır. Allah Rasûlü kendi görüşünün daha doğru ve uygulanabilir olduğunu kabul ettirmek için insanları aracı olarak görmemektedir. Onun insanların görüşlerine saygı duymadaki amacı, ortaya çıkan sorunu çözmek için en faydalı kararı uygulamaktır. Doğru olduğu için birinin görüşünü kabul etmek, lider için pozitif bir yaklaşımdir.

\section{Sahâbenin Hz. Peygamber'e Muhalefeti}

\section{A. Hubâb b. Münzir}

Allah Rasûlü 624 tarihinde meydana gelen Bedir Savaşı'nda Kureyş'ten önce savaş meydanına gidip su kuyularına hâkim olma niyetindeydi. Bu amaçla o, Medine tarafına en yakın ve düşmana da en uzak olan kuyunun çevresine ordunun karargâh kurmasını belirtti. Ancak ordu içerisinde bir er olan Hubâb b. Münzir burasının savaşılabilecek uygun bir yer olmadığı düşüncesindeydi, o, kendi görüşünü açıklamadan önce: "Ya Rasûlallah! Burası sizin savaş stratejisi olarak belirlediğiniz bir yer mi, yoksa ileri veya geri gidemeyeceğimiz Allah'ın belirlediği bir yer mi?" diye sordu. Bu soruya Hz. Peygamber: "Burası Allah'ın belirlediği bir yer değil, bizzat benim savaş stratejisi olarak düşündüğüm bir yerdir" şeklinde cevap verince Hubâb b. Münzir: "Ya Rasûlallah! Burası savaş stratejisi olarak karargâh kurulacak bir yer değildir. Orduyu buradan kaldır.

\footnotetext{
37 Vâkıdî, Kitâbü'l-Meğâzzî, II, 446; Taberî, Târîhu'l-Ümem, II, 91.

38 Hamidullah, Muhammed, Hz. Peygamber'in Savaşlan, trc. Salih Tuğ, Yağmur Yayınları, İstanbul 1991, s. 118-119.

39 Vâkıdî, Kitâbü'l-Meğĝâi, II, 454; İbn Sa'd, et-Tabakâtül-Kübrâ, II, 51.

40 Vâkıdî, Kitâbü'l-Meğâzî̀, II, 446.
} 
Bizler, Kureyş ordugâhına en yakın yere karargâh kuralım ve su alacağımız kuyu dışındakileri kapatalım. Düşmanla savaşırken su ihtiyacımızı buradan karşılarız, fakat onlar su içemezler." Bu teklif üzerine Hz. Peygamber: “Görüşünü ortaya koydun" diyerek bunun araştırılmasını istedi. Yapılan keşif neticesinde Hubâb’ın görüşünün doğru olduğu anlaşılınca Allah Rasûlü kendi görüşünden vaz geçerek Hubâb'ın düşüncesini kabul etti. Böylece o, ordunun yerini değiştirerek Hubâb'ın işaret ettiği kuyunun çevresine yerleşti ve diğer kuyuları ise kumla kapattırdı. Ancak Rasûlullah daha sonra açık bırakılan kuyudan müşriklerin su almalarına müsaade etti. ${ }^{41}$

Hubâb b. Münzir ordu içerisindeki statüsünü önemsemeden savaşın kazanılması için Rasûlullah'ın düşüncesinin yanlış olduğunu belirtme cesaretini göstermiştir. Bu durum karşısında hem $\mathrm{Hz}$. Peygamber hem de sahâbîler Hubâb'1 bu cesur yürekliliğinden dolayı kınamamışlardır. Daha da önemlisi; Allah Rasûlü'nün, Hubâb b. Münzir'i: "Sen, er statüsünde olan birisin, hangi hak ve yetkiyle benim görüşümün yanlışlığını söyleme cüretinde bulanabilirsin" diyerek azarlamamış, aksine onun görüşünün doğru olup olmadığının araştırılmasını istemiştir. Burada can alıcı nokta; sahâbeye böyle bir ortamı hazırlayan kişinin özelliğidir. Eğer Allah Rasûlü, sahâbînin teklifini olumlu karşılamayıp sert karşılık verseydi, acaba diğer sahâbîler benzeri olaylarda görüş ve düşüncelerini ifade ederken rahat davranabilirler miydi?! O halde bu tarz ortamların oluşturulmasında en büyük sorumluluk, liderlere düşmektedir.

\section{B. Namazı Hatalı Kıldıran Hz. Peygamber'in Sahâbîler Tarafın- dan Uyarılması}

Hz. Muhammed her ne kadar peygamber olsa da, insan merkezli bir yapıya sahiptir. Çünkü Kur'ân, onun insanlar gibi olduğuna vurgu yapmaktadır. ${ }^{42} \mathrm{Bu}$ sebeple $\mathrm{o}$, insan olmasının doğal bir sonucu olarak zaman zaman beşerî zaaflar göstermektedir. Bu bağlamında o, namaz kıldırdığı esnada kendisine Zü'l-Yedeyn isimli sahâbî veya başka birisi tarafından: “Ey Allah'ın Resûlü! Namaz mı kısaldı, yoksa unuttunuz mu?43 ya da "Namazda bir değişiklik mi oldu?" denildi. O: "Ne oldu?" diye sordu. Onlar: "Şöyle şöyle namaz

\footnotetext{
41 Vâkıdî, Kitâbû'l-Meğâzî, I, 61; İbn Hişâm, es-Sîratü'n-Nebeviyye, I-II, 620; Taberî, Târîhu'l-Ümem, II, 29.

42 Kehf, 110; Fussilet, 6.

43 Müslim, Mesâcid, 97.
} 
kıldınız" veya "Beş rekat namaz kıldırdınız." ${ }^{44}$ dediler. Bunun üzerine Hz. Peygamber dizlerini büktü, kıbleye döndü ve iki defa secde yaptı, selam verdikten sonra bizlere yönelerek şöyle dedi: "Namazda herhangi bir değişiklik olsaydı, mutlaka sizlere haber verirdim. Fakat ben de sizin gibi bir insanım. Sizin unuttuğunuz gibi ben de unuturum. Unuttuğum zaman bana hatırlatınız. Sizden biri namazında şüpheye düşerse, doğruyu araştırsın ve o şekilde namazını tamamlasın, sonra selam verip iki defa secde yapsın." 45 Başka bir rivayette ise Hz. Peygamber namazdayken bazı âyetleri atlayarak okumuş, uyarılınca da "Onu bana neden hatırlatmadınız diyerek sahâbîyi uyarmıştır." ${ }^{46}$

Hz. Peygamber namazda yaptığı yanlışlık kendisine haber verilince herkesin takdir edeceği bir davranış örneği ortaya koymuştur. Yani o, bir peygamber olarak kendisine böyle bir hatırlatma yapıldığı zaman hiçbir gurura ve kibre kapılmadan veya bunu ihsas ettirmeden "Ben de sizin gibi bir insanım. Sizlerin unuttuğunuz gibi ben de unutabilirim" diyerek insanlarda olan beşeri zaafların kendisinde de olduğunu söylemesi, karşıdakileri cesaretlendirmekte, kendilerine olan güvenlerini arttırmakta ve yanlışlığı kim yaparsa yapsın usulünce söylenmesi gerektiğini önemle vurgulamaktadır. Ayrıca sahâbîler, Hz. Peygamber' in insan olma gerçeğini asla göz ardı etmemişlerdir. Yani sahâbe, Hz. Peygamber'den yanlış yanlış bir eylemde bulunmasına kayıtsız kalmamiştır. Allah Rasûlü'nün bir idareci olarak en önermli özelliği; oto kontrol mekanizmasını dinamik hale getirmesidir. Bu mekanizma işlevsel olduğu müddetçe makam ve mevki sahibi insanların yapacakları fiil ve eylemlerde daha dikkatli olmaları gerekmektedir. Böyle bir muhalefetin temel hedefi, insanların açıklarını bulmak veya eksikliklerini ortaya çıkartmak değil, hakikati bulma arayışıdır. Nübüvvet makamında bulunan $\mathrm{Hz}$. Peygamber'in dinî konularda uyarılması karşısında onun: “Ben bir peygamberim, bu konuları sizlerden daha iyi bilirim, sizler kim oluyorsunuz da beni uyarma cüretinde bulunuyorsunuz" deme yerine böyle bir uyarıyı olgunlukla karşılayıp, muhalefetin önündeki engelleri kaldırması oldukça önemlidir.

\footnotetext{
44 Müslim, Mesâcid, 91-94.

45 Buhârî, Salât, 31.

46 Ebû Dâvud, Süleyman b. Eşas, Sünenü Ebî Dâvud, Çağn Yayınları, İstanbul 1992, Salât, 158.
} 


\section{Hendek Savaşı}

Mekkeli müşrikler, Müslümanları tamamen yok etmek amacıyla 627 yılında çeşitli grupların katılımıyla büyük bir orduyla Medine üzerine doğru harekete geçtiği haber alan Hz. Peygamber, düşmanın saldırısını önlemek amacıyla şehrin zayıf noktalarına hendek kazdırttı. Ancak savaş esnasında Benû Kureyzâ'nın müşriklerle ittifak yaparak Müslümanları iki ateş arasında bırakması, Müslümanlar çok zor durumda birakmıştı. Allah Rasûlü böyle hassas bir durumda düşman kuvvetlerini parçalamak için harekete geçti. Bu amaçla o, Hendek Savaşı'nın yaklaşık bir ay kadar uzaması üzerine sahâbenin korkusunu ve endişesini gidermek için muhasaraya Mekkelilerin yanında katılan Gatafân kabilesinin liderleri Uyeyne b. Hisn ve Hâris b. Avf ile gizlice görüştü. Görüşmesinde Kureyş'e destek olmamaları karşılığında Medine'nin yıllık hurma hasılatının üçte birini vermeyi teklif etti. Onlar, Rasûlullah'tan Medine hurmalarını üçte ikisini talep ettiler, fakat Allah Rasûlü bu teklifi kabul etmedi. Bunun üzerine onlar da Hz. Peygamber'in üçte birlik teklifini kabul ettiler. Ancak Hz. Peygamber bu antlaşmayı imzalanmadan önce konuyu Evs ve Hazrec' in liderleri olan Sa'd b. Muaz ve Sa'd b. Ubâde ile istişare etti. Onlar: "Ya Rasûlallah! İstediğin bir şey varsa onu yapalım. Allah'ın sana emrettiği bir şey varsa da onu yapmamız gerekir. Bizim için ne yapmak istiyorsun?" şeklindeki cevabına Allah Rasûlü: "Hayır, onu sizin için yapmak istiyorum. Vallahi Arapların bir yaydan çıkan ok gibi üzerinize geldiğini ve her taraftan size saldırdıklarını gördüm ve bundan dolayı onların size karşı olan gücünü kırmak için böyle antlaşma yapmak istedim." Bunun üzerine Sa'd b. Muaz, bunun vahye değil, Rasûlullah'ın düşmanın gücünü bölmek düşüncesine dayandığını öğrenince şöyle dedi: “Biz ve onlar Allah'a ortak koşar ve putlara tapardık. O dönemde onlar bizim misafirimiz olmadıkça veya satın almadıkça bir tek hurmamıza bile göz dikemezdi. Şimdi İslâm ile şereflendiğimiz bu sırada mı onlara mallarımızı vereceğiz?" Bunun üzerine Hz. Peygamber: "Nasıl istersen” şeklinde karşılık verince Sa'd b. Muaz: "Yazılı olan metni aldı ve yırttı" Böylece Allah Rasûlü iki liderin kararlılığını görünce Gatafân ile antlaşma yapmaktan vazgeçti. ${ }^{4}$

Hz. Peygamber'in düşmanı bölmek amacıyla yaptığı bu antlaşma, devletin geleceği açısından oldukça önemlidir. Çünkü Müslümanlar hem sayı bakımından azdı hem de ihanete

47 Vâkıdî, Kitâbû'l-Meğâzî̀, II, 477-478; İbn Hişâm, es-Sîratü'n-Nebeviyye, III-IV, 223; Taberî, Târîhu'l-Ümem, II, 94. 
uğramışlardı. Böyle bir durumda atılabilecek en önemli adım, düşman saflarını zayıflatmaktı. Bu amaçla Rasûlullah'ın çeşitli kabile liderleriyle yaptığı antlaşma büyük bir başarı olarak algılanmalıdır. Ancak Allah Rasûlü'nün toplumun çıkarlarını düşünerek yapmaya çalıştığ 1 bu antlaşmaya Medine'nin önde gelen liderleri muhalefet onun ederek pratiğe dökülmesine izin vermemişlerdir. Çünkü onlar böyle bir antlaşmanın kendileri için bir taviz olacağını düşünmekteydiler. Hz. Peygamber kendi düşüncelerinde ssrar etmeyip onların görüşlerinin doğruluğunu kabul ettiği için bu antlaşmayı onaylamamıştır. Rasûlullah, sahâbenin bu tavrını kendisine karşı muhalefet olarak değil, düşünce özgürlüğü çerçevesinde değerlendirmiştir.

\section{Hudeybiye Anlaşması}

Hz. Peygamber 628 yılında yaklaşık olarak bin dört yüz veya bin beş yüz kişiden oluşan ashâbıyla birlikte yerine Abdullah b. Ümmü Mektûm'ü bırakarak Medine'den Mekke'ye Kâbe'yi ziyaret etmek maksadıyla yola çıktı. Müslümanlar yanlarına sadece yolcu kılıçlarını aldılar. Hz. Peygamber gerekirse savaşmak için silah alınması yolundaki teklifleri kabul etmedi. Kurbanlık olarak yetmiş deve aldı. Durumu iyi olan sahâbîler de kendi kurbanlıklarını aldılar. Kureyş, Hz. Peygamber'in Mekke'ye doğru geldiğini haber alınca, Hâlid b. Velîd komutasında bir öncü birliğini ona mani olması için gönderdi. Bu durumdan haberdar olan Rasûlullah barışı arzuladığı için başka bir yoldan gitmeyi tercih etti. Hudeybiye denilen yere gelindiği zaman o, ordunun burada karargâh kurmasını istedi. Elçiler bazında görüşülmeye başlandı ve anlaşma aşamasına gelindi. ${ }^{48}$

Illk müzakere ve muhalefet, vesikanın başına yazılacak olan ifade üzerinde meydana geldi. Hz. Peygamber, kâtibi Ali b. Ebî Tâlib'e vesikanın başına: "Bismillahirrahmanirrahîm" yazmasını emretti. Kureyş'in temsilcisi olan Süheyl b. Amr buna itiraz ederek: "Biz, Rahman ve Rahîm'in ne anlama geldiğini bilmiyoruz" dedi ve "Bismikellâhümme" ifadesinin yazılmasını istedi. Müslümanların itirazına

48 İbn Hişâm, es-Sîratü'n-Nebeviyye, III-IV, 308-316; Taberî, Târîhu'l-Ümem, II, 115-122; İbnü'l-Esîr, el-Kâmil, II, 200-203; İ̉n Kesîr, el-Bidâye , IV, 165-169. 
rağmen Rasûlullah, ifadenin Süheyl b. Amr'ın isteği doğrultusunda yazılmasını emretti. ${ }^{9}$ Böylece Hz. Peygamber' in kararlılığı sayesinde bu sorun aşılmış oldu.

İkinci olarak anlaşmayı yapan tarafların kullanacakları unvan da sorun oldu. Allah Rasûlü, kâtibi Ali b. Ebî Tâlib'e: "Bu, Allah'ın Rasûlü Muhammed ile Süheyl b. Amr arasında imzalanan sulh antlaşmasıdır." cümlesini yazmasını istedi. Kureyş delegesi buna da itiraz etti ve şöyle dedi: “Biz, senin Allah'ın Rasûlü olduğunu kabul etseydik, seni Kâbe'yi ziyaret etmekten men etmez ve seninle savaşmazdık" diyerek cümleden "Rasûlullah" kısmının çıkarlıp yerine "Muhammed b. Abdullah" yazılmasını talep etti. Bunun üzerine o: "Sizler, beni yalanlasanız da ben, Allah'ın Rasûlüyüm"50 diyerek Ali b. Ebî Tâlib'e "Rasûlullah" lafzını silip "Muhammed b. Abdullah" yazmasını emretti. Ancak Ali b. Ebî Tâlib, "Rasûlullah lafzını asla silemeyeceğini" söyleyince Rasûlullah, "Onun yerini bana göster" dedi. Ali b. Ebî Tâlib, Rasûlullah'a yerini gösterince o, "Rasûlullah" lafzını sildi ve "Muhammed b. Abdullah" ibaresini yazd1..$^{51}$ Tartışlan bu madde Hz. Peygamber'in çabaları sonucunda son şeklini aldı.

“Mekkeli Müslümanlardan veya müşriklerden biri Medine'ye giderek Müslümanlara iltica ederse, Kureyş̧'e iade edilecek, fakat Müslümanlardan biri Mekke'ye gelirse, Kureyş onu teslim etmeyecektir" maddesi Müslümanların tepkisine neden oldu. Bu esnada Süheyl b. Amr'ın oğlu Ebû Cendel elleri ve ayakları zincirli olarak Müslümanların karargâhına geldi. Süheyl b. Amr oğlunu görünce: “Ey Muhammed! Seninle üzerinde anlaşacağım şeyin ilki, oğlumu bana iade etmendir" dedi. Hz. Peygamber ise bu madde üzerinde henüz anlaşmadıklarını söyleyince Kureyş delegesi: “Oğlumun geri verilmemesi durumunda hiçbir şey üzerinde seninle anlaşmayacağım" dedi. Daha sonra Ebû Cendel: "Ey Müslümanlar! Müslüman olarak geldiğim halde dinim konusunda beni fitneye düşüren, bana her türlü işkenceyi yapan müşriklere beni iade mi edeceksiniz?" dedi. Ebû Cendel'in ko-

49 İbn Hişâm, es-Sîratü'n-Nebeviyye, III-IV, 317; İbn Sa'd, et-Tabakâtü'l-Kübrâ, II, 77. Buhârî, Şurût, 15.

50 İbn Hişâm, es-Sîratü'n-Nebeviyye, III-IV, 317; Buhâri, Şurût, 15; Taberî, Târîhu'l-Ümem, II, 122; İbnü'l-Esîr, el-Kâmil, II, 204; İbn Kesîr, el-Bidâye , IV, 169; Kastallânî, Ebu'l-Abbâs Şihâbüddin Ahmed, İrşâdü's-Sârî li Şerhi Sahîhi'l-Buhârî, Dâru'l-Fikr, Beyrut 1990, VI, 217-237.

51 Buhârî, Sulh, 6; Müslim, Cihâd, 92; Kastallânî, İrşâdü's-Sârî, VI, 174-178. 
Hz. Peygamber Döneminde Düşünce Özgürlüğü ve Muhalefet

nuşması ve görüntüsü Müslümanları derinden sarsmıştı. Hz. Peygamber: “Ey Ebû Cendel! Sabret. Allah sana sabretmenin karşılığını verecektir, sen ve seninle birlikte olan mustaz'aflara Allah yakında bir kurtuluş yolu verecektir. Biz bu kavimle bir sulh antlaşması yaptık. Bundan dolayı seni onlara veriyoruz" dedi. ${ }^{52}$ Bu duruma çok içerleyen Hz. Ömer, Rasûlullah'a gelerek: "Sen gerçekten Allah'ın Peygamberi değil misin?" dedi. Hz. Peygamber: "Evet, Allah'ın peygamberiyim" dedi. Yine Hz. Ömer "Bizler hak yolda, düşmanlarımız ise batılda değil mi?" diye sorunca Hz. Peygamber: "Evet" dedi. "Ben, Allah'ın Rasûlü'yüm, hiçbir konuda ona isyan edemem, o bana yardım edecektir" diye karşıllk verdi. ${ }^{53}$

"Sil ve yaz" emrini, kâtip olarak orada bulunan Hz. Ali'nin yerine getirmemesi/muhalefet etmesi Rasûlullah tarafından olgunlukla karşılanmıştır. Muhtemelen Allah Rasûlü, Hz. Ali'nin bu yaklaşımını içinde bulunduğu duygusal duruma bağlamış olacak ki, onun bu tavrını hoşgörüyle karşılamıştır. Sahâbe, dünyevî konularda akıl ve mantıklarına uygun düşmeyenlere muhalefet etme hususunda cüretkâr davranmıştır. Bir şeyin yapılmasını Hz. Peygamber bile emretmişse, sahâbe sözlü ve fiili olarak tepkilerini ortaya koymuştur. Bu antlaşmaya en sert muhalefet eden ise Hz. Ömer olmuştur. O, söylemlerinde çok aşırı gitmesine rağmen Rasûlullah'ın yapıcı tavrı karşısında daha sonraki dönemlerde pişmanlığını ifade etmiştir. Gerek Hz. Ali'nin gerekse de Hz. Ömer'in, Hz. Peygamber'e karşı muhalefeti modern dünyada pek alışık olunmayan bir durumdur. Benzeri hadiseler günümüzde meydana gelse, olayın failleri en ağır bir şekilde cezalandırılmaktan kurtulamazlar. Bu sebeple Allah Rasûlü'nün muhalefet edenlere karşı gösterdiği müsamaha, fikir ve ifade hürriyetinin gelişmesine önemli derecede katkı sağlamıştır. $\mathrm{O}$, hiçbir zaman düşünce özgürlüğünün, fikir ve ifade hürriyetinin karşında durmamış, engellerin kaldırılması için yoğun bir çaba göstermiştir.

52 Buhârî, Şurût, 15; İbn Kesîr, el-Bidâye , IV, 169-170; Kastallânî, İrşâdü’s-Sârî, VI, 217-237; İbn Hacer, Fethu'l-Bârî, V, 388-415.

53 İbn Hişâm, es-Sîratü'n-Nebeviyye, III-IV, 317; Buhâri, Şurût 15; Taberî, Târîhu'l-Ümem, II, 116-124; İbnü'l-Esîr, el-Kâmil, II, 200-204; İbn Kesîr, el-Bidâye , IV, 173-176; Kastallânî, İrşâdü's-Sârî, VI, 217-237; Diyârbekrî, Târîhu'l-Hamîs, II, 358-372; Hamidullah, İslam Peygamberi, I, 253-260. 


\section{E. Hâtıb b. Ebî Beltea}

Hudeybiye Antlaşması'nın “Arap kabilelerinden, isteyen kabile iki taraftan birisiyle ittifak kurabilecektir" maddesine göre Huzâa kabilesi Müslümanlarla, Benû Bekir kabilesi de Mekkelilerle ittifak yapmıştı. Bu antlaşmanın üzerinden iki yıl geçtikten sonra $\mathrm{Ku}$ reyş'in desteğini alan Benû Bekir kabilesinin Huzâa kabilesine saldırması üzerine ${ }^{54}$ Allah Rasûlü Hudeybiye Antlaşması'nın kendisine tanıdığı hakka dayanarak fetih hazırlıklarına başladı. Hâtıb b. Ebî Beltea büyük bir gizlilik içerisinde yürütülen bu hazırlıkları Sâre isimli bir kadınla Mekkeliler'e bildirmeye çalıştı. Ancak Hz. Peygamber bundan haberdar olunca bu kadının yakalanmasını emretti. Yakalanan kadının üzerinden: "Hâtıb b. Ebî Beltea'dan Mekkelilere" şeklinde başlayan ve savaş hazırlıklarını belirten bir mektup bulundu. Rasûllüllah, Hâtıb’1 çağırtıp: “Ey Hâtıb! Bu ne iştir?" diye sorunca Hâtıb: "Ya Rasûlallah! Benim için acele etme. Ben, Kureyş'e antlaşma ile bağlı bir kişiyim. Fakat ben, Kureyş'in samimi bir ferdi olamadım. Beraberinizde muhâcirlerden şu kadar kimseler vardır ki, bunların Mekke'de ailelerini, mallarını koruyacak birtakım akrabaları var, benim ise hiç kimsem yok. Nesebim yönünden olan bu boşluğu Mekkeliler arasında minnettarlık kazanarak ailemi himaye etmek istedim. Yoksa dinimden döndüğüm için böyle bir yola başvurmuş değilim. Ben, Müslüman olduktan sonra kesin olarak küfre razı olmam." şeklinde özrünü beyan edince affedilmiştir. ${ }^{55}$

Hâtıb b. Ebî Beltea, Hz. Peygamber tarafından gizlilik içerisinde yürütülen fetih hazırlıklarını müşriklere bildirmeye teşebbüs etmesi nedeniyle vatana ihanet suçunu işlemiştir. Çünkü o, askerî planları deşifre etmek suretiyle hem Müslümanları tehlikeye atmış hem de Rasûlullah'ın kesin emrine muhalefet etmiştir. O, bu yaptıklarıyla vatana ihanet suçundan yargılanıp en ağır bir şekilde cezalandırılmayı hak etmiştir. Buna rağmen Rasûlullah, onun duygularına yenilerek işlediği suçu affetmiş, arkadaşlarına da yaptıklarından dolayı da onu eleştirmemelerini belirtmiştir. İnsanlar hata yapmaya müsait varlıklardır. Bu gerçekten hareketle idarecilerin yanlışlık yapıldığında karar vermeden önce olayı en ince ayrıntılarına kadar araştırmaları gerekmektedir.

54 Vâkıdî, Kitâbü'l-Meğâzî, II, 571-605; İbn Hişâm, es-Sîratü'n-Nebeviyye, III-IV,395397; İbn Sa'd, et-Tabakâtül-Kübrâ, II, 102; Taberî, Târîhu'l-Ümem, II, 154.

55 İbn Hişâm, es-Sîratü'n-Nebeviyye, III-IV, 398-399; Buhârî, Cihâd, 14-15. 


\section{F. Huneyn Savaşı}

Daha önceki savaşlarda elde edilen ganimetler, devletin $1 / 5$ hissesi ayrıldıktan sonra savaşan Müslümanlar arasında dağıtılıyordu. Ancak Huneyn Savaşı'nda elde edilen ganimetlerde Allah Rasûlü farklı bir metod takip etti. Çünkü Huneyn Savaşı'na katılanlar arasında Mekke'nin fethinden sonra İslâm'a giren yeni Müslümanlar da bulunmaktaydı. Bu sebeple Hz. Peygamber, bu savaşta ele geçirilen ganîmetlerin büyük bir bölümünü kalpleri İslâm'a 1sınsın diye Arap kabilelerinin reislerine verdi. Ayrıca, Kureyş'e de büyük bir miktar verdi. Ensâr'a ise hiçbir şey vermedi. Ensâr'dan bazıları kendilerine ganimetten pay verilmediği için üzüntülerini belirtti. Kimileri de: "Hz. Peygamber kavmiyle buluştu, artık bizi hatırlamaz oldu." dedi. Hatta bazıları: "Hâlâ kılıçlarımızdan onların kanları damlıyor. Bu, Allah rızası gözetilmeyerek yapılan bir taksimdir" dediler. Hazrec' in reisi olan Sa'd b. Ubâde, Rasûlullah'ın huzuruna gelerek şunları söyledi: "Ya Rasûlallah! Ensâr'dan bir topluluk, ganîmet dağıtımında yapmış olduğun uygulamadan dolayı sana karşı içlerinde bir burukluk hissettiler." Bunun üzerine Hz. Peygamber: "Ey Sa'd! Sen bu konuda ne düşünüyorsun?" diye sordu Sa'd: "Ben de kavmimin bir ferdiyim" diye cevap verince Hz. Peygamber, Sa'd'dan Ensâr'1 toplamasını istedi. Ensâr toplaninca Rasûlullah geldi ve Allah'a hamd ve senâdan sonra şöyle buyurdu: "Ey Ensâr! Sizden sâdır olduğunu duyduğum ve içinizde bana karşı bir burukluğuna dair söylentiler var." Bunun üzerine sahâbenin ileri gelenleri: "Ya Rasûlallah! Bizim ileri gelenlerimiz öyle sözler söylemezler. Bunları söyleyenler gençlerimizdir" dediler. Bunun üzerine Hz. Peygamber Ensâr'a şöyle hitap etti: "Dalâlet üzere olduğunuz halde Allah sizi hidayete kavuşturmadı mı? Yoksul ve fakir olduğunuz halde Allah sizi zengin yapmadı mı? Birbirinize düşman olduğunuz halde Allah kalplerinizi benim vasıtamla birleştirmedi mi?" Ensâr, Allah Rasûlü'nün hakikatleri söylemesi karşısında: “Evet, Ya Rasûlallah! Söylediğin gibidir. Allah ve Rasûlü'nün üzerimizde minnet ve faziletleri vardır" diyerek cevap verdiler. Sahâbenin bu samimi itirafları karşısında Hz. Peygamber konuşmasına şöyle devam etti: "Ey Ensâr topluluğu! Niçin bana açı cevap vermiyorsunuz?" Onlar da mahcubiyet içerisinde: "Sana nasıl cevap verelim? Fazilet ve minnet sendendir" dediler. Bunun üzerine Allah Rasûlü: "İsteseydiniz şöyle diyebilirdiniz ve bu sözünüzde de doğruyu söylemiş olurdunuz. Ayrıca bu sözün doğruluğu herkes tarafından da kabul görürdü: Herkes seni yalanladığı bir zamanda bize geldin seni doğruladık. Hiç kimse sana yardım 
etmemişti, sana yardım ettik. Memleketinden kovulmuştun, seni barındırdık. Yoksul idin, sana baktık. Ey Ensâr! Sizin Müslümanlığınıza kefil olduğum halde, bir takım kimseleri kazanmak, onları İslâm'a 1sındırmak için verdiğim dünyalıktan dolayı bana içerlediniz mi? Ey Ensâr! Başkaları deve ve koyun sürülerini alıp memleketlerine giderken siz, Allah'ın Rasûlü'nü alıp yurdunuza gitmeye razı değil misiniz? Nefsim elinde olan Allah'a yemin olsun ki, eğer hicret olmasaydı, Ensâr'dan bir fert olmayı tercih ederdim. Eğer bütün bir halk bir yoldan gitse, Ensâr da bir yoldan gitse, ben Ensâr'ın gittiği yoldan giderim. Ya Rabb! Sen Ensâr'ı, çocuklarını ve torunlarını bağışla." 56

Ensâr, samimi ve içten söylenen bu sözler karşısında hep bir ağızdan: "Ya Rasûlallah! Yalnız bu mal ganimeti değil, dilersen baba ve dedelerimizden miras olarak aldığımızı da onlara taksim et. Bizim maksadımız senin şerefli rızandır. Bizim nazarımızda dünya malının zerre kadar önemi yoktur. Biz payımıza ve hissemize düşene razıyız" diyerek özürlerini ifade ettiler. Hz. Peygamber, Ensâr'ın bu sözlerinden memnun olarak şöyle dedi: “Ey Ensâr! Sizin inancınızdaki samimiyete güvenim vardır. Kureyş ise İslâm’a yeni girmiştir. Şimdiye kadar meydana gelen savaşlarda Müslümanlar tarafından pek çok yenilgiye uğratıldılar. Onların kalplerini yatıştırmak için fazla hisse verdim. Onlar evlerine koyun ve develerle gidecek. Siz ise Rasûlullah ile gideceksiniz. Buna razı olmaz mısınız?" Ensâr: "Ya Rasûlallah! Sana yakın olmak bizim için dünyadan ve dünyanın içindekilerden daha hayırlıdır. Allah üzerimizden gölgenizi eksik etmesin" dediler. ${ }^{57}$

Hz. Peygamber, Kureyş'e ganimetten fazla pay vermesinin sebebini de bu şekilde anlatarak tenkitçi gençlerin yüreğine su serpmiştir. Allah'ın elçisi bu duygu yüklü konuşmasıyla ensârı ve onların gençlerini son derece etkiledi. Öyle ki, az önce kendisini tenkit edenler, artık

56 İbn Hişâm, es-Sîratü'n-Nebviyye, III-IV/489-500; İbn Sa'd, et-Tabakâtü'l-Kübrâ, II, 115119, Buhârî, Meğâzî, 56; Taberî, Târîhu'l-Ümem, II, 186-187; İbnü'1-Esîr, el-Kâmil, II, 281282; İbn Kesîr, el-Bidâye , IV, 346-348; Câbirî, Muhammed Âbid, Arap-İslâm Siyasal Akll, trc. Vecdi Akyüz, Kitapevi Yayınlanı, İstanbul 2001, s. 155.

57 İbn Hişâm, es-Sîratü'n-Nebviyye, III-IV/489-500; İbn Sa'd, et-Tabakâtü'l-Kübrâ, II, 115119, Buhârî, Meğâzî, 56; Taberî, Târîhu'l-Ümem, II, 186-187; İbnü'l-Esîr, el-Kâmil, II, 281282; İ̉n Kesîr, el-Bidâye , IV, 346-348; Câbirî, Arap-İslâm Siyasal Akl, s. 155; Esad, Mahmud, İslâm Tarihi, sad. Ahmet Lütfü Kazancı-Osman Kazancı, Marifet Yayınları, İstanbul 1995, ss. 733-734. 
Hz. Peygamber Döneminde Düşünce Özgürlüğü ve Muhalefet

pişman olarak gözyaşı dökmüşlerdi. Bunda Hz. Peygamber'in duygulara hitap etmedeki ustalık ve sanatının çok büyük etkisi olduğu görülmektedir. ${ }^{58}$

İslâmiyet ensârın omuzlarında belli bir noktaya yükselmiştir. Müslümanlar Mekke'den kovulduklarında kendileri onlara sahip çıkmıştır. Yani Hz. Peygamber'in başarısında onların payı oldukça büyüktür. Şimdi bütün bunların meydana gelmesinde onların büyük bir etkisi varken, ganimet paylaşımında arka plana itilmeleri kendilerini oldukça rahatsız etmiştir. Çünkü insanların çoğunda mevcut olan mala düşkünlük, onlarda da kendini göstermiştir. Onlar, Hz. Peygamber'in davranışının arka planını düşünemediklerinden kendilerine haksızlık edildiğini sesli bir şekilde düşünmeye başladılar. Gençler, tecrübeli insanlar gibi davranmaktan uzak olduklarından dolayı, tepkilerini ortaya koymaktan çekinmemişlerdir.

Hz. Peygamber'in kendisi hakkında söylenenleri duyunca, sorunun çözümü için karşılıklı görüşmeyi tercih etmesi, onun düşünce ve ifade hürriyetine ne kadar önem verdiğini göstermektedir. $\mathrm{O}$, sahâbenin endişelerinin yersiz olduğunu veciz bir şekilde ifade ettikten sonra, çeşitli sorularla hem akla hem de duygulara hitap ederek onlara doğru yolu göstermiştir. Ayrıca Allah Rasûlü'nün bireyleri muhatap alma yerine toplumu dikkate alarak konuşması, olayın sosyolojik yönünün daha önemli olduğunu vurgulamak içindir. Böyle davranmakla Hz. Peygamber, münferit olan problemleri toplumun geneline yayarak çözme eğiliminde olmuş ve böylece herkesin üzerine düşen hisseyi almasını arzu etmiştir. İnsan, hayatı boyunca değişik türde problemlerle karşı karşıya kalır. Ne var ki çoğu insan, problemlerini çözmede metod yetersizliğinden dolayı başarılı olamaz. Böyle bir durumu yaşamamak için sorunlarla karşı karşıya kalındığı zaman, teennî ile hareket edip Hz. Peygamber'in akılcı ve mantıkçı yöntemlerini kullanmak insanlar arasında sosyal barışı tesis etmeye büyük katkı sağlayacaktır.

\section{Sonuç}

Düşünce özgürlüğü, fikir ve ifade hürriyeti insanın doğuştan getirdiği temel hak ve özgürlüklerin en önemlisidir. İnsanı insan yapan ve onu diğer varlıklardan ayıran en belirgin özelliği, kendini ifade edebilmesidir. Bu sebeple insanın bulunduğu her ortamda kendini ifade edebilmesine, duygu ve düşüncelerini özgür bir şekilde belirtmesine imkân

\footnotetext{
58 Seyfullah Kara, Peygamber Döneminde Gençlik, Ağaç Kitabevi, İstanbul 2009, s. 105.
} 
tanınmalıdır. Bu özelliği kısıtlayıcı veya engelleyici unsurlarla mücadele edilmeli ve insanların kendilerini gerçekleştirmelerine olanak sağlanmalıdır. Ayrıca buna muvazi olarak muhalefet kültürü de olumlu ve katkı sağlayıcı bir özelliğe büründürülerek dinamik hale getirilmelidir. Muhalefet, liderin veya kişinin eksikliklerini veya açıklarını ortaya çıkarmak değil, doğruyu ve hakikati arama eylemi şeklinde algılanmalıdır.

Hz. Peygamber hem düşünce özgürlüğünün hem de muhalefetin gelişmesine önemli derecede katkı sağlamıştır. Onun bulunduğu ortamlarda sahâbîler hiçbir etki altında kalmadan duygu ve düşüncelerini söyleme cesaretini gösterebilmişlerdir. Çünkü böyle bir imkânı her şeyden önce Allah Rasûlü oluşturmuştur. Rasûlullah toplumun genelini ilgilendiren önemli olaylar öncesi doğru ve sağlıklı bir karara ulaşmak amacıyla ashâbıyla istişarede bulunmayı gelenek haline getirmişti. Konu hakkında görüşlerine başvurulan sahâbîler de medeni çerçeve içerisinde duygu ve düşüncelerini belirtirdi. Hz. Peygamber de ortaya konulan görüşlerden (kendi görüşüne aykırı olsa bile) en uygununu almayı tercih ederdi. Allah Rasûlü bu yaklaşımıyla insanlar üzerinde asla baskı unsuru oluşturmamış, hür iradeleriyle duygu ve düşüncelerin açıklanmasını sağlamıştır. Onun bu tarzdaki yaklaşımı, kendi görüşlerini kabul ettirmeye değil, en doğrusunu bulmaya yöneliktir. Hz. Peygamber kendisine karşı gösterilen muhalefeti anlayış içerisinde karşılamış, muhataplarını asla rencide etmemiştir. $\mathrm{O}$, bu davranışlarıyla her zaman eleştirilmeye açık olduğunu göstermeye çalışmıştır. Eleştirinin ve muhalefetin özgürce yapılabildiği yerlerde oto kontrol mekanizması aktif olacağı için kişi veya kişiler daha dikkatli olacaklardır. Bu mekanizmanın her zaman işlevsel olabilmesi, liderlerin tutum ve davranışlarına bağlıdır. Bu sebeple Hz. Peygamber'in böyle bir ortamın oluşturulması için ortaya koyduğu örnek davranışlar oldukça önem arz etmektedir.

\section{Kaynakça}

Ahmed b. Hanbel. Müsned, Çağrı Yayınları, İstanbul 1992.

Aksu, Ali, "İfk Olayı Üzerine Değerlendirme", Cumhuriyet Üniversitesi İlahiyat Fakültesi Dergisi, VIII/1, Sivas 2004.

Beyhakî, Ebû Bekir Ahmed b. Hüseyin. Delâilü'n-Nübüvve, Dâru'l-Kütübi'lIlmiyye, Beyrut 1988.

Buhârî, Ebû Abdullah Muhammed b. İsmail. Sahîhu'l-Buhârî, Çağrı Yayınları, İstanbul 1992.

Câbirî, Muhammed Âbid. Arap-İslâm Siyasal Aklı, trc. Vecdi Akyüz, Kitapevi Yayınları, İstanbul 2001. 
Hz. Peygamber Döneminde Düşünce Özgürlüğü ve Muhalefet

Diyârbekrî, Hüseyin b. Muhammed b. Hasan. Târîhu'l-Hamîs fì Ahvâli Enfesi Nefîs, Dâru'l-Kütübi'l-Ilmiyye, Beyrut 1971.

Ebû Dâvud, Süleyman b. Eşas. Sünenü Ebî Dâvud, Çağrı Yayınları, İstanbul 1992.

Esad, Mahmud. İslâm Tarihi, sad. Ahmet Lütfü Kazanc1-Osman Kazanc1, Marifet Yayınları, İstanbul 1995.

Ğazâlî, Muhammed. Fıkhu's-Sîre, Dâru'l-Kalem, Beyrut 1994.

Hamidullah, Muhammed. Hz. Peygamber'in Savaşları, trc. Salih Tuğ, Yağmur Yayınları, İstanbul 1991.

Hudarî Bey, Muhammed. Nûru'l-Yakîn fì Sîrati Seyyidi'l-Mürselîn, Dâru'lHadîs, Misir 1992.

İbn Hişâm, Abdülmelik. es-Sîretü'n-Nebeviyye, Dâru İbn Kesîr, Kahire ts.

İbn Kesîr, Ebu'l-Fidâ İsmail. el-Bidâye ve'n-Nihâye, Dâru'l-Hadis, Kahire 1994.

İbn Sa'd, Muhammed. et-Tabakâtü'l-Kübrâ, Dâru'l-Kütübi'l-Ilmiyye, Beyrut 1990.

İbnü'l-Esîr, Izzüddin Ebi'l-Hasen Ali b. Ebi'l-Keram. el-Kâmil fi't-Târîh, Dâru Sâdır, Beyrut 1979.

Kara, Seyfullah. "İfk Olayının Etkileri ve Olayla ilgili Ortaya Konan Tavırlar", Atattürk Üniversitesi İlahiyat Fakültesi, XV, Erzurum 2001. , Peygamber Döneminde Gençlik, Ağaç Kitapevi Yayınları, İstanbul 2009.

Kastallânî, Ebu'l-Abbâs Şihâbüddin Ahmed. İrşâdü's-Sârî li Şerhi Sahîhi'lBuhârî, Dâru'l-Fikr, Beyrut 1990.

Muhammed, Riza. Muhammed Dâru'l-Kalem, Beyrut 2003.

Müslim, Ebu'l-Hüseyin Müslim b. Haccâc. Sahîhu Müslim, Çağrı Yayınları, İstanbul 1992.

Nesâî, Ebû Abdurrahman Ahmed b. Şuayb. Sünenü Nesâ̂, Çağrı Yayınları, İstanbul 1992.

Süheylî, Abdurrahman. er-Ravdu'l-Unuf, Dâru'l-Fikr, Beyrut ts.

Taberî, Ebû Ca'fer Muhammed b. Cerîr. Târîhu'l-Ümem ve'l-Mülûk, Dâru'lKütübi'l-Ilmiyye, Babeyrut 1997.

Tirmizî, Ebû Isa Muhammed b. Isa b. Sevre. Sünenü Tirmizî, Çağrı Yayınları, İstanbul 1992.

Vâkıdî, Muhammed b. Ömer. Kitâbü'l-Meğâzẑ̂, Dâru'l-Fikr, Beyrut 1984. 